ZOOLOGIA 28 (2): 247-249, April, 2011

doi: $10.1590 /$ S1984-46702011000200014

\title{
A new species and a new record of Nesticus from southeastern Brazil (Araneae: Nesticidae)
}

\author{
Bárbara T. Faleiro \& Adalberto J. Santos
}

\begin{abstract}
Departamento de Zoologia, Instituto de Ciências Biológicas, Universidade Federal de Minas Gerais. Avenida Antonio Carlos 6627,31270-901 Belo Horizonte, MG, Brazil.E-mail: btf8@hotmail.com; oxyopes@yahoo.com
\end{abstract}

\begin{abstract}
A new species of Nesticus is described based on specimens collected during a structured inventory of the Reserva Particular do Patrimônio Natural Mata Samuel de Paula, state of Minas Gerais, Brazil. Nesticus ivone sp. nov. can be recognized by the paracymbium of the male palpus with three not hooked processes, and by the presence of a central vulval plate in the female epigynum. Additionally, a new record is presented for Nesticus taim Ott \& Lise, 2002, extending the known distribution range of this species northwards.
\end{abstract}

KEY WORDS. Minas Gerais, taxonomy, spider, Nesticus taim.

The spider family Nesticidae Simon, 1894 includes many species that live in caves, some of which have adaptations for this environment (GERTSCH 1984). However, recent studies have described species of epigean habitats, mostly from litter and foliage (Lehtinen \& SaARisto 1980, Otт \& Lise 2002). Species of Nesticidae are small, ecribellate spiders. They are recognized by a combination of characters, including a rebordered labium, male palp with well developed basal paracymbium and female palpal claw large (Brescovit et al. 2002, PaQuin \& Hedin 2005). Currently the family is composed of nine genera, of which three have been recorded from Brazil (Eidmannela Roewer, 1935, Nesticella Lehtinen \& Saaristo, 1980, and Nesticus Thorell, 1869 - Rodrigues \& Buckup 2007, Platnick 2010).

Nesticus is the richest genus within the family, with five species reported from Brazil (Platnick 2010). Males of this genus have the paracymbium relatively larger than the paracymbium of males of Nesticella, bearing at least two processes (Rodrigues \& Buckup 2007). Females, on the other hand, can be diagnosed by the prominent epigynum (GeRTSCH 1984) and the vulval gland with a gland duct (LeHTinen \& SAARISTO 1980, Отт \& Lise 2002). The Brazilian species are known only from the southern region and have been recorded in lower vegetation strata and in litter (Отт \& Lise 2002).

The scarcity of species of Nesticidae known from Brazil, as well as their restricted geographic distribution, can be a result of sampling deficiencies and lack of attention from local spider taxonomists. This is illustrated in the results of this study, in which we describe a new species based on specimens collected in a recent spider diversity inventory in southeastern Brazil (DE MARIA et al. 2009). The species is apparently related to two species of Nesticus described from southern Brazil, Nesticus brignolii Ott \& Lise, 2002 and Nesticus calilegua Ott \& Lise, 2002 (see Отт \& Lise 2002). This assignment is, however, tentative, owing to the lack of phylogenetics studies on Nesticidae. In addition, a new record is presented for Nesticus taim Ott \& Lise, 2002, expanding its known distribution range northwards.

\section{MATERIAL AND METHODS}

The species described in this study is based on specimens collected with pitfall traps in the Reserva Particular do Patrimônio Natural Mata Samuel de Paula, Nova Lima, state of Minas Gerais, an area of semideciduous Atlantic forest (SALINo et al. 2009). All material examined is deposited in the arachnid collection of the Coleções Taxonômicas da Universidade Federal de Minas Gerais, Belo Horizonte (UFMG, curator: A.J. Santos). Specimens were examined and illustrated using a Leica M205C stereoscopic microscope with a camera lucida. Digital images were taken with a Leica DFC500 digital camera attached to a Leica M205C stereoscopic microscope. Pictures taken in several focal planes were assembled in multifocus images with the software Leica Applications Suite Version 3.3.0 (Leica Inc.). All measurements are in millimeters and were made using an Olympus SZ40 stereoscopic microscope with a micrometer eyepiece. The female genitalia was excised, immersed for two hours in a pancreatin solution (see Alvarez-Padilla \& Hormiga 2008) to remove soft tissues, and illustrated immersed in ethanol. The terminology used in descriptions follows GERTSCH (1984).

\section{TAXONOMY}

\section{Nesticus ivone sp. nov. Figs 1-5}

Type material. Male holotype (UFMG 2565) from BRAzIL, Minas Gerais: Nova Lima (Reserva Particular do Patrimônio Natural Mata Samuel de Paula, $\left.20^{\circ} 00^{\prime} \mathrm{S} 43^{\circ} 52^{\prime} \mathrm{W}, 967 \mathrm{~m}\right), 12$ 18.X.2006, J.P.P. Pena-Barbosa et al. leg. Female paratype (UFMG 

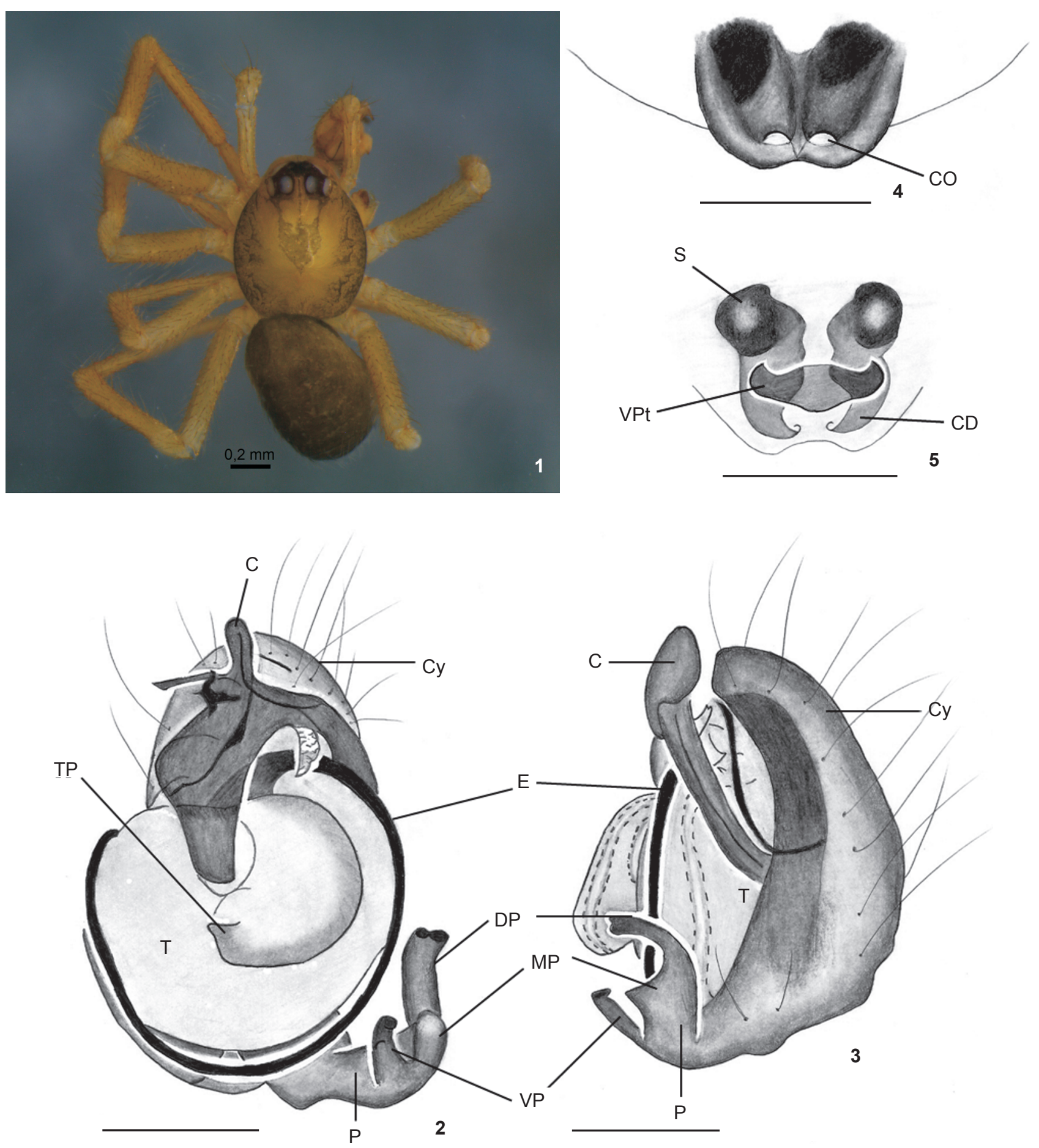

Figures 1-5. Nesticus ivone sp. nov.: (1-3) male holotype: (1) dorsal view; (2) left palpus, ventral view; (3) ditto, retrolateral view; (4-5) female paratype: (4) epigynum, ventral view; (5) female internal genitalia, dorsal view. (C) Conductor, (CD) copulatory duct, (CO) copulatory opening, (Cy) cymbium, (DP) paracymbium dorsal process, (E) embolus, (MP) paracymbium median process, (P) paracymbium, (S) spermathecae, (T) tegulum, (TP) tegular process, (VP) paracymbium ventral process, (VPt) vulval plate. Scale bars: $0.1 \mathrm{~mm}$. 
2566) from the same locality, 29.IV-01.V.2006, J.P.P. PenaBarbosa et al. leg.

Diagnosis. Nesticus ivone sp. nov. males resemble $N$. brignolii in the tegulum wider than cymbium, with a central, curved tegular process (Fig. 2). They can be distinguished by both dorsal and ventral paracymbium processes not hooked in $N$. ivone sp. nov. and by the presence of a paracymbium median process (Figs 2 and 3). Females can be recognized by the thick, not coiled copulatory ducts, the absence of vulval gland, and by the presence of a central vulval plate (Fig. 5).

Description. Holotype male. Carapace pale-yellow with grayish-brown pigmentation on the edges and in the middle, eyes circled in grayish-brown (Fig. 1). Thoracic fovea circular. Chelicerae, endites and labium pale-yellow. Sternum grayishbrown. Legs pale-yellow. Abdomen homogeneously greyishbrown. Tegular process located in the center of the tegulum, curved and ending in a small, rounded tip. Embolus filiform, curved in clockwise direction in the left palp. Conductor long vertically, with rounded edges (Figs 2 and 3). Paracymbium with three processes (ventral, median and dorsal), all with rounded edges. Dorsal process larger than the others (Fig. 3). Measurements. Total length 1.32. Carapace 0.64 long, 0.53 wide, 0.42 high. Clypeus 0.05 high. Chelicerae 0.22 long, 0.12 wide. Endites 0.16 long, 0.07 wide. Labium 0.03 long, 0.14 wide. Sternum 0.44 long, 0.38 wide. Abdomen 0.66 long, 0.42 wide, 0.46 high. Legs: I. femur 0.70 , patella 0.22 , tibia 0.64 , metatarsus 0.49 , tarsus 0.36 , total 2.43; II. $0.51,0.18,0.38,0.36,0.33,1.79$; III. 0.49, $0.16,0.24,0.22,0.20,1.32$; IV. $0.72,0.18,0.60,0.49,0.35,2.36$. Palpus: femur 0.29, patella 0.09 , tibia 0.09 , tarsus 0.31 , total 0.79 .

Paratype female. Color as in male. Epigynum slightly prominent (Fig. 4). Spermathecae globose. Fertilization ducts inconspicuous (Fig. 5). Measurements. Total length 1.10. Carapace 0.51 long, 0.38 wide, 0.33 high. Clypeus 0.01 high. Chelicerae 0.20 long, 0.11 wide. Endites 0.09 long, 0.07 wide. Labium 0.03 long, 0.11 wide. Sternum 0.27 long, 0.27 wide. Abdomen 0.57 long, 0.36 wide, 0.36 high. Legs: I. femur 0.31, patella 0.12 , tibia 0.27 , metatarsus 0.24 , tarsus 0.22 , total 1.18 ; II. $0.31,0.11,0.24,0.18,0.20,1.05$; III. 0.27, 0.09, 0.18, 0.16, $0.18,0.90$; IV. 0.36, 0.12, 0.29, 0.24, 0.22, 1.25. Palpus: femur 0.16 , patella 0.05 , tibia 0.09 , tarsus 0.12 , total 0.44 .

Natural history. All the specimens were collected in the litter in an area of semi deciduous Atlantic Forest.

Distribution. Known only from the type locality.

Etymology. The specific name is a matronym honoring the senior author's mother, Ivone Izabel Teixeira.

Remarks. Male and females were not collected together, but were matched based on body size, shape and color pattern.

\section{Nesticus taim Ott \& Lise, 2002}

New record. Brazil, Minas Gerais: Ouro Preto (Parque Estadual do Itacolomi, $\left.20^{\circ} 22^{\prime} \mathrm{S} 43^{\circ} 32^{\prime} \mathrm{W}\right), 2-4$.XI.2007, K.P. Santos et al. leg., 1\#m (UFMG 2213).

Remarks. This specimen was collected in a pitfall trap placed in Eucalyptus plantation with a regenerating, Atlantic Forest undergrowth.

\section{ACKNOWLEDGEMENTS}

We thank AngloGold Ashanti for authorizing field work in its particular natural reserve and for financial support for the expeditions. To Ivan L.F. de Magalhães and Gracielle F.B.P. Ferreira for suggestions on the illustrations. To Cnpq for financial support for the main author in form of an undergraduate scholarship. To CNPQ (Processes 472976/2008-7 and 300498/ 2009-8) and Instituto Nacional de Ciência e Tecnologia dos Hymenoptera Parasitóides da Região Sudeste Brasileira (http:// www.hympar.ufscar.br/) for grants to second author.

\section{LITERATURE CITED}

Álvarez-Padilla, F. \& G. Hormiga. 2008. A protocol for digesting internal soft tissues and mounting spiders for scanning electron microscopy. Journal of Arachnology 35: 538-542.

Brescovit, A.D.; A.B. Bonaldo; R. Bertani \& C.A. Rheims. 2002. Araneae, p. 303-343. In: J. AdIs (Ed.). Amazonian Arachnida and Myriapoda. Sofia, PENSOFT Publishers, VI+590 p.

De Maria, M.; A.J. Santos; A.R. Benedetti; B.T. Faleiro; G.H.F. Azevedo; I.L.F. Magalhães; J.P.P.P.barbosa; M.T.T. Santos; P.F. Vilela \& U. Oliveira. 2009. Aracnídeos/Araneofauna, p. 209-223. In: AngloGold/Ashanti (Org.). Biodiversidade da Mata Samuel de Paula. Belo Horizonte, Anglogold Ashanti, 296p. GerTsch, W.J. 1984. The spider family Nesticidae (Araneae) in North America, Central America, and the West Indies. Texas Memorial Museum Bulletin 31: 1-91.

LeHTINEN, P.T. \& M.I. SAARISTO. 1980. Spiders of the Oriental-Australian region II Nesticidae. Annales Zoologici Fennici 17: 47-66.

Oтт, R. \& A.A. Lise. 2002. On Nesticus from Meridional South America (Araneae, Nesticidae). Iheringia, Série Zoologia 92 (4): 59-71.

Paquin, P. \& M. Hedin. 2005. Nesticidae, p. 178-180. In: D. Ubick; P. Paquin; P.E. Cushing \& V. Roth (Eds). Spiders of North America: an identification manual. Paughkeepsie, American Arachnological Society, V+377p.

Platnick, N.I. 2010. The world spider catalog. Version 11.0. American Museum of Natural History. Available online at: http:/ /research.amnh.org/iz/spiders/catalog [Accessed: 01/VIII/2010].

Rodrigues, E.N.L. \& E.H. Buckup. 2007. O gênero Nesticella Lehtinen \& Saaristo (Araneae, Nesticidae) no Brasil. Revista Brasileira de Zoologia 24 (3): 673-676.

Salino, A.; G. Heringer; L.E. Andrade; P.H.A. Melo \& T.E. Almeida. 2009. Flora/Florístico, p. 33-133. In: AngloGold/Ashanti (Org.). Biodiversidade da Mata Samuel de Paula. Belo Horizonte, Anglogold Ashanti, 296p.

Submitted: 22.Ix.2010; Accepted: 20.III.2011.

Editorial responsibility: Antonio D. Brescovit 